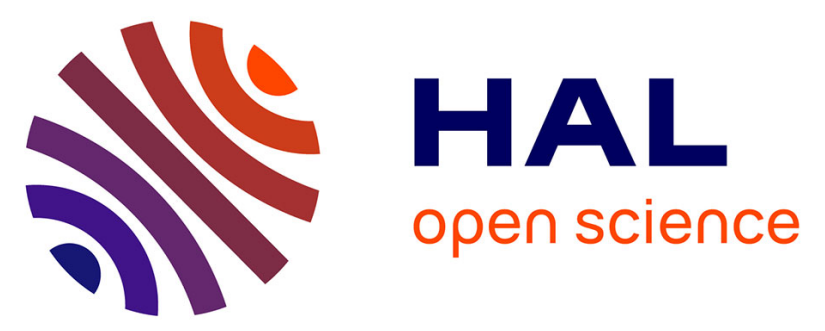

\title{
Gradual diversions of the Rio Pastaza in the Ecuadorian piedmont of the Andes from 1906 to 2008: role of tectonics, alluvial fan aggradation and ENSO events
}

Carolina Bernal, Frédéric Christophoul, Jean-Claude Soula, José Darrozes, Luc Bourrel, Alain Laraque, José Burgos, Séverine Bès de Berc, Patrice Baby

\section{- To cite this version:}

Carolina Bernal, Frédéric Christophoul, Jean-Claude Soula, José Darrozes, Luc Bourrel, et al.. Gradual diversions of the Rio Pastaza in the Ecuadorian piedmont of the Andes from 1906 to 2008: role of tectonics, alluvial fan aggradation and ENSO events. International Journal of Earth Sciences, 2012, pp.101: 1913-1928. 10.1007/s00531-012-0752-9 . hal-00652362v4

HAL Id: hal-00652362

https://hal.science/hal-00652362v4

Submitted on 17 Sep 2012

HAL is a multi-disciplinary open access archive for the deposit and dissemination of scientific research documents, whether they are published or not. The documents may come from teaching and research institutions in France or abroad, or from public or private research centers.
L'archive ouverte pluridisciplinaire HAL, est destinée au dépôt et à la diffusion de documents scientifiques de niveau recherche, publiés ou non, émanant des établissements d'enseignement et de recherche français ou étrangers, des laboratoires publics ou privés. 


\title{
Gradual diversions of the Rio Pastaza in the Ecuadorian piedmont of the Andes from 1906 to 2008: role of tectonics, alluvial fan aggradation, and ENSO events
}

\author{
Carolina Bernal, Frédéric Christophoul, Jean-Claude Soula, \\ José Darrozes, Luc Bourrel, Alain Laraque, \\ José Burgos, Séverine Bès de Berc, Patrice Baby \\ International Journal of Earth Sciences (Geologische Rundschau), 101: 1913-1928 \\ DOI: $10.1007 / \mathrm{s} 00531-012-0752-9$ \\ hal-00536576 \\ Received: 8 April 2011 / Accepted: 12 January 2012 / Online: 31 January 2012
}

\begin{abstract}
C. Bernal, F. Christophoul, J-C. Soula, J. Darrozes, L. Bourrel, A. the regular monthly discharge and the lack of actual Laraque and P. Baby,

UMR 5563 GET, Université de Toulouse-CNRS-IRD-OMPCNES,14 Avenue Edouard Belin, 31400 Toulouse, France. frederic.christophoul@get.obs-mip.fr

'normal' floods during the inter-ENSO periods.

Keywords: avulsion, tectonics, sedimentation, fluvial morphology, Andes, Ecuador
\end{abstract}

C. Bernal, chavelacarola@yahoo.com.mx

J-C. Soula, soula@get.obs-mip.fr

J.Darrozes, darrozes@get.obs-mip.fr

L. Bourrel, bourrel@get.obs-mip.fr

A. Laraque, alain.laraque@ird.fr

Patrice Baby, patrice.baby@ird.fr

\section{J. Burgos,}

Petroamazonas, Av. Naciones Unidas E7-95 y Shyris, Quito, Ecuador, 4to piso, Quito, Ecuador

jose_burgos@petroamazonas.ec

\section{S. Bès de Berc,}

BRGM, Direction Régionale Réunion et Interrégionale Océan Indien, 5, rue Sainte-Anne - BP 906, 97478 Saint-Denis Cedex, France.

s.besdeberc@brgm.fr

ABSTRACT The successive courses of the Rio Pastaza in the upper Amazonian Puyo plateau (Ecuador) during the past century have been followed using historical maps, aerial photographs, satellite imagery, topographic and river long profiles, and field studies. The abrupt change in direction of the Rio Pastaza from transverse to longitudinal was a result of two avulsions occurred between 1906 and 1976 at the braided-meandering transition of the former alluvial plain. These avulsions are related to aggradation at the toe of a braided piedmont fan prograding on to a hinterland-dipping topographic slope formed by ongoing tectonic backtilting. The main avulsion proceeded by annexation of a south-dipping depression created in front of the cordillera by backtilting of the plateau. A partial and gradual avulsion having occurred upstream of the former site between 1976 and 2008 is marked by the progressive predominance of a newly formed inner branch. Tectonic backtilting enhanced aggradation upstream of the initial site while it offered the newly avulsed channel a still more favourable way along the cordillera by creating a westward lateral slope. The correlation between ENSO events and the occurrence of the 1976-to-2008 avulsions strongly suggests that the triggers of the avulsions were the floods caused by the high water and sediment discharges associated with ENSO (La Niña) events contrasting with

\section{INTRODUCTION}

The present paper presents an example of migrations of a river of the Ecuadorian Andes, the Rio Pastaza in the regional context of a low amplitude active tectonic backtilting over the past century (1906 to 2008). As often on an orogenic foothill, these migrations are results of avulsion, the process whereby a river abruptly changes its course. These avulsions occurred on a $400 \mathrm{Km}^{2}$ area where the Rio Pastaza exits a $13,700 \mathrm{Km}^{2}$ drainage basin by mean of a deep gorge incised in the Eastern Cordillera after a $155 \mathrm{~km}$ long course. They provide a good opportunity of investigating the conditions of the morphological response of a river in a context of tectonic driven surface tilting and alluvial sedimentation.

The parameters favouring and/or triggering these avulsions such as sediment supply, tectonic tilting and ENSO-controlled local climatic characteristics will be discussed. This study is based on historical maps, aerial photography, satellite images, field data and interviews with inhabitants.

\section{2 - BACKGROUND}

\section{2.a - Structure of the Ecuadorian Andes}

The Amazonian versant of the Ecuadorian Andes (Fig. 1) can be divided into four morphotectonic units.

The Western Cordillera and Interandean depression consist of Upper Cretaceous-Paleogene formations (Kennerley, 1980; Lavenu et al., 1992; Reynaud et al., 1999) unconformably overlain by Neogene/Quaternary deposits (Barberi et al., 1988; Lavenu et al., 1992; Barragán et al., 1996; Hungerbühler et al., 2002; Winkler et al., 2005).

The Eastern cordillera is comprised of Paleozoic through Upper Cretaceous metamorphic rocks blanketed by late Miocene to Pliocene volcanic/volcaniclastic formations involved in a large-scale fault-bend fold, and intruded by Quaternary volcanoes (Baldock, 1982; Barberi et al., 1988; Lavenu et al., 1992).

The Subandean Zone is separated from the Eastern cordillera by the west dipping Subandean Thrust fault and includes the Abitagua cordillera (essentially granitic) and two antiformal thrust stack culminations, the Cutucu and 
Napo domes made up of Jurassic to Neogene strata (Baby et al., 1999; Bes de Berc et al., 2005). These culminations are separated by an axial depression in which occurred the studied avulsions. The Subandean Zone is bounded to the east by the Subandean Frontal Thrust fault which emerges at the base of the Cutucu and Napo thrust stacks related antiforms (Fig.1A). Between 2.77 Ma and $190 \mathrm{ka}$, the depression was affected by a basaltic volcanism, leaving lavas and scoria cones (Hoffer et al., 2008). A piedmont megafan (Mera fan) had formed there during the Pleistocene (Tschopp, 1953; Baby et al., 1999; Bes de Berc et al., 2005).The apex of this fan was cut by an oxidized and hardened surface (Mera surface, Heine, 1994, 2000; Bès de Berc et al., 2005) which formed during the LGM, 21,000 cal. years ago (Bès de Berc et al., 2005; Bernal et al., 2011). Since then, the Mera surface - geographically known as the Puyo plateau - has been affected by tectonic backtilting and arching (Bès de Berc et al., 2005; Bernal et al., 2011) (Fig. 2 and 3A).

\section{2.b - The Puyo and Villano plateaus}

The Puyo plateau (= the Mera surface) was originally the western part of a piedmont pediment, gently dipping eastward, now separated from its eastern prolongation, the Villano surface, by an erosional depression (Bes de Berc et al., 2005; Bernal et al., 2011) formed along a low-angle normal fault (Fig. 1B). The Puyo plateau (Fig.2) has now a westward dip of $0.6^{\circ}$ in average and $0.9^{\circ}$ in its central part including the study area. Its elevation varies from $1,100 \mathrm{~m}$ a.s.l. in its central-eastern edge to $900 \mathrm{~m}$ a.s.l. at the northern and southern tips and along its inner boundary, in front of the cordillera. In a south-north profile the Puyo plateau appears as a $70 \mathrm{~km}$ wide gentle arch with an amplitude of $190 \mathrm{~m}$ (Bès de Berc et al., 2005) (Fig. 3A). This arch forms an east-west culmination east of the town of Puyo (Puyo high, Bes de Berc et al., 2005) (Fig. 2 and $3 \mathrm{~A})$. This culmination constitutes the main divide between the drainage basin of the Rio Pastaza and that of the Rio Napo, which is the other major river of the region. The Villano surface has kept a shallow $\operatorname{dip}\left(<0.3^{\circ}\right)$ to the east. Its elevation in its western edge is 800 to $500 \mathrm{~m}$ a.s.1.. The restoration of the original surfaces from a series of crosssections shows a normal offset of 300 to $400 \mathrm{~m}$ (Fig. 1B). The normal fault is related to the propagation of the Subandean frontal thrust and fold. The average tilting rate of the Puyo plateau since the LGM is $\sim 3-4.5 .10^{-50} \mathrm{yr}^{-1}$ $\left(0.5-0.8 \mu \mathrm{rad} \mathrm{yr}^{-1}\right.$ or $\left.0.008 \mathrm{~cm} \mathrm{~km}^{-1} \mathrm{yr}^{-1}\right)$. The average uplift of the plateau edge with respect to its inner boundary is of $0.6-0.85 \mathrm{~cm} \mathrm{yr}^{-1}$, higher than in the cordilleras for the same period (4-6 mm year ${ }^{-1}$, Bès de Berc et al, 2005).

Two local topographic highs appear in the Puyo plateau (Fig. 3B). In the north, the fault-related Mirador anticline culminates at $\sim 1,400 \mathrm{~m}$ asl (Bès de Berc et al., 2005) (Fig. 1B). In the south, the volcanic edifice formed by the preserved Pliocene lavas and scoriae (Hoffer et al., 2008) culminates at $\sim 1,100 \mathrm{~m}$ asl, $\sim 80$ to $100 \mathrm{~m}$ above the plateau (Fig. 3B).

\section{2.c - The Rio Pastaza in the Ecuadorian Andes}

The Rio Pastaza is sourced in the Western Cordillera (Fig. 2), and is the only Ecuadorian river that traverses the Eastern Cordillera. Upstream of the Subandean front, its catchment covers an area of $13,700 \mathrm{Km}^{2}$.

The Rio Pastaza sensu stricto is transverse and formed by the junction of two longitudinal branches flowing in the Interandean Depression (Fig. 2). Downstream of the confluence, the Rio Pastaza traverses the Eastern Cordillera and the Abitagua cordillera through a narrow and deep valley $\sim 12 \mathrm{~km}$ wide and 2,900 to $1,300 \mathrm{~m}$ deep. Where debouching into the Puyo plateau, the valley widens abruptly and the river slope decreases to form an alluvial fan with a $\sim 6 \mathrm{~km}$ radius. The Rio Pastaza diverges into two branches which form an abrupt bend to the south and flow southward along the front of the Eastern Cordillera where it has formed a wide braidplain in continuity with the Puyo fan. These two branches re-join immediately south of the Volcanic Complex (Fig. 2). The Rio Pastaza receives two major transverse tributaries from the west, the Rios Llushin (basin area $=1,015 \mathrm{~km}^{2}$ ) and Palora (basin area $=2,350$ $\mathrm{km}^{2}$ ) (Fig. 2). At its confluence with the Rio Llushin, the course of the western branch of the Rio Pastaza forms a sharp eastward bend in prolongation of the western course of the Rio Llushin (Fig. 2 and 5A) while the eastern branch forms a more rounded bend before re-joining the western branch. Downstream, the Rio Pastaza exits the Puyo plateau after having flowed $\sim 12 \mathrm{~km}$ along the plateau edge (Fig. 2). The deposits on the younger terraces of the Pastaza grade downstream into aggrading modern deposits forming the Puyo fan and the southern Pastaza braidplain (Fig. 7). These modern deposits are rather coarse (boulders up to $50 \mathrm{~cm}$ in diameter) and their thickness is greater than 7-8 m.

The average annual discharge of the Rio Pastaza from 1917 to 2004 is $121 \mathrm{~m}^{3} \mathrm{~s}^{-1}$ at the Hydroagoyan dam, near Baños, and varies between $\sim 185 \mathrm{~m}^{3} \mathrm{~s}^{-1}$ in 1975 (La Niña event) to $85-90 \mathrm{~m}^{3} \mathrm{~s}^{-1}$ in 1981 and 1991 (El Niño event) (Laraque et al., 2009) (Fig. 4B). The average monthly discharge varies from $181 \mathrm{~m}^{3} \mathrm{~s}^{-1}$ in July and $82.5 \mathrm{~m}^{3} \mathrm{~s}^{-1}$ in January (Laraque et al., 2009) (Fig. 4A).

\section{2.d-Climatic setting}

The present climate in the Ecuadorian Amazonia is hot and wet, especially in the piedmont with average annual precipitation of over $3,000 \mathrm{~mm}$ all along the cordillera front, and $\geq 4,500 \mathrm{~mm}$ near Puyo at $1,000 \mathrm{~m}$ asl (Hastenrath, 1981; Gomez, 1994). At Puyo, the monthly average rainfall is greater than $300-350 \mathrm{~mm}$ all year, with a maximum in March and April (Gomez, 1994). At Baños (Fig. 4A, location on Fig. 2), $35 \mathrm{~km}$ upstream of our study area, the monthly average rainfall varies from $\sim 80 \mathrm{~mm}$ in January to $\sim 200 \mathrm{~mm}$ in June. At the Cusubamba station in the northern Interandean Depression (Fig. 3A), the average annual precipitation is considerably lower and the monthly average rainfall varies from $\sim 15 \mathrm{~mm}$ in July and August to $\sim 75 \mathrm{~mm}$ in March and November (Laraque et al., 2009) (Fig. 4A).

3 - THE RECENT MIGRATIONS OF THE RIO PASTAZA IN THE PUYO PLATEAU 
The migrations of the Rio Pastaza in the past century (Rio Pindo Grande, Rio Salomon, Rio Chico in the north; (from 1906 to 2008) have been traced using a topographic Rio Chigunsimi and Rio X in the centre; Rio Putuimi in the map published in 1906, aerial photographs taken in 1976, south) are still active but have acquired since then a satellital images and field observations between 1992 and contributary pattern. In the west, around and southeast of 2008. 1976 paths were constructed using 6 photographs the village of Shell, bifurcating-rejoining channels are taken during the aerial photography campaign of the frequently seen separating $250 \mathrm{~m}$ wide amygdaloidal Instituto Geografico Militar of Ecuador. Photographs were swells, which are likely to represent former longitudinal georeferenced, orthorectified and then mosaicked. The baidbars. This abandoned braidplain is similar in size and resulting mosaic is shown in Figure 6. The paths of 1987 morphology to the better preserved or active Pastaza and following years (1992, 2000 and 2002) are based on braidplain in the south. In the east, the abandoned meander Landsat and Aster satellite images. These images were loops have wavelength and amplitude in general greater georeferenced, orthorectified and then binarized in order to than those of the present day rivers and extend to the north enlight the active channels (Fig. 8). Field observations in the area now drained by the lower Rios Pindo Grande were carried out during the years 2003 to 2008 (Fig. 5). No and Salomon (Fig. 7) which now flow southward. The area press documents have been found, even for the more recent where the 1906-to-1976 avulsion occurred corresponds to avulsions. Eye witnesses have a clear memory of the the braiding-meandering transition of the ancient valley avulsions having occurred since 1976 (but not of the exact and only a sedimentary ridge constitutes the divide time when they occurred). No one remember the time between the present-day Rio Pastaza and Rio Puyo when the Rio Pastaza flowed to the east along the Volcanic drainage basins.

Complex but peoples over 70 still living in the area are rare. The exact time when the avulsions occurred thus remains unknown, in particular in the 1906 to 1976 period. However, the snapshots in the evolution of the river system provided by the images enable us to distinguish 6 "stages" (Fig. 8). Complexity of the braid channels network will be described by the Braiding Index (BI). BI is defined as the sum of the active channels length divided by the reach length.

\section{3.a - Stage 1 (observed in 1906)}

The 1906 map shows that the Rio Pastaza flowed along the northern and then eastern boundaries of the Pliocene Volcanic Complex (Figs. 5A and 8). Today, the eastern portion of this path is occupied by the Rio Puyo a left-bank tributary of the former Rio Pastaza (Fig. 8), which forms a sudden $90^{\circ}$ bend toward the east at the junction with the former Pastaza valley. A distance of $7 \mathrm{~km}$ separates this junction from the eastern branch of the Pastaza. The eastern part of the abandoned valley is now occupied by the unnamed river we termed 'Rio $X$ ' (Fig. 8). The western portion of this abandoned valley is presently occupied by the upper Rio Chigunsimi. This document also
reveals the presence of a minor left-bank tributary of the Rio Llushin flowing along the front of the cordillera.

The poor quality of the 1906 document did not enable us to characterize the channel pattern of the Rio Pastaza and the characteristics of the Pastaza valley at this time eastward until the present Pastaza-Puyo confluence (Figs. However, information on this valley is provided by the 7 and 8). Downstream of the bifurcation 1 , a $1000 \mathrm{~m}$ wide 1976 photographs (Figs. 5A and 7). Although the area was upstream reach striking SW-NE (130) is composed of wide already highly vegetated (in the east) or occupied by tea braided channels. At the contact with the Volcanic plantations (in the west), the 1976 photographs show Complex, the river becomes a single channel for $\sim 1.7 \mathrm{~km}$, evidence of an abandoned floodplain oriented west-east and then widens and recovers its braided morphology. The along the northern boundary of the volcanic complex active channels are located in the left side of the baidplain between the Pastaza braidplain in the west, and the in contact with the Volcanic Complex.

eastward bend of the Rio Puyo in the east (Fig. 7). This The 1976 photographs also reveal that two avulsions floodplain is wider $(1-2 \mathrm{~km})$ than the present-day valleys are at the origin of the abandon of the pre-1976 floodplain of the Rio X and Rio Puyo and incised by these rivers. and both occurred between 1906 and 1976. The Tracing the abandoned drainage network reveals a sedimentary ridge constituting the wing gap between the braided/distributary pattern changing eastward into a eastern branch of the Pastaza 1976 and the Pastaza 1906 relatively wide meander belt (Fig. 7). Some of the rivers (the present Rio Chigunsimi) is somewhat higher than the 
Pastaza braidplain $(\sim 15 \mathrm{~m})$, thus indicating a large accumulation of sediment. The present windgap between the Rio Chingusimi and the Rio $\mathrm{X}$ is only 4-6 $\mathrm{m}$ higher than the site of the avulsion of the Rio Chingusimi into the Rio Putuimi (Fig. 7). As for the Pastaza - Chigunsimi divide, the ridge is sediment-made. A well-marked knick point appears in the long profile of the Rio Chigunsimi strongly suggesting either a capture of the Chigunsimi by the Rio Putuimi or an annexation of the Rio Putuimi by the is rapid in the region, this confirms that no channel activity Rio Chigunsimi. As the Putuimi valley is relatively deep has occurred for several tens years.

but narrow, this avulsion must have occurred after the Pastaza avulsed to the south. It is noteworthy that both avulsion sites are situated at the braiding-meandering transition of the pre-1976 floodplain (Fig. 7).

\section{3.c- Stage 3 (observed in 1987)}

In 1987 (Fig. 8), the Río Pastaza has the same overall configuration as in 1976. The western branch $\mathrm{X}^{\prime}$ exhibits braided channels characterized by a low braiding parameter $(\mathrm{BI}=1.8$, cf. Schumm, 1977). Compared to 1976, this branch exhibits the same width but less active channels. The morphology of the eastern branch X" varies from single-channel to braided with a very low braiding parameter $(\mathrm{BI}=0.5)$. This branch is less wide and exhibits less active channel than in 1976. To the south, a series of diverging channels separate from the main channel and rejoin the river downstream of the Llushin confluence. The remaining southward-flowing main channel $\left(\mathrm{Y}^{\prime}\right)$ presents the same braiding characteristics $(\mathrm{BI}=1.6)$ as upstream of the divergence point 2 . The separate channels (Y") appear as single meandering streams.

\section{3.d- Stage 4 (observed in 1992)} In 1992 (Fig. 8), the point of bifurcation between the reconstructed by joining the upper portion of the eastern
branches $X^{\prime}$ and $X^{\prime}$ 'is displaced $\sim 1.8 \mathrm{~km}$ to the south. The branch of the Pastaza, the western portion of the Rio branch $X^{\prime \prime}$ is reduced to a straight single channel. The Chigunsimi, the Rio $X$ and the lower Rio Puyo. This branch $X^{\prime}$ has a braiding parameter $\mathrm{BI}=1.8$. The channels, profile shows two narrow highs only $15 \mathrm{~m}$ and $\sim 5 \mathrm{~m}$ above active in 1987 having separated from $X^{\prime}$ at bifurcation the profile (Fig. 8B), which are the sedimentary ridges point 2 (channels Y'), are now abandoned except the related to the two avulsions that occurred between 1906 and eastern one. Downstream of point 2, the braiding 1976. The profile is however rather regular with an parameter of the main channel decreases $(\mathrm{BI}=0.9)$

\section{3.e - Stage 5 (observed in 2000)}

In 2000 (Fig. 8), the overall configuration is similar as in 1992 and 1987, but the eastern branch X" is now very narrow. No active channels separate from the western branch X', but traces of abandoned parallel channels have been observed east of the main stream. The braiding parameter of this western reach increased $(\mathrm{BI}=3.1)$ to the south of the point 1 and $\mathrm{BI}=2.0$ to the south of point $\mathrm{Y}^{\prime}$.

\section{3.f - Stage 6 (observed in 2002)}

The 2002 image (12/09/2002, Fig. 8) does not differ much from 2000. The branch $X^{\prime \prime}$ keeps reducing its width. The channel $X^{\prime \prime}$ is inactive and the main channel $X^{\prime}-Y^{\prime}$, preserves its high braiding parameter $(\mathrm{BI}=3.0)$ north of point 2 and $\mathrm{BI}=2.0$ south of point 2 . The braid channels are wider and the braid islands narrower, which strongly suggests that practically all the flow was directed into the western branch.
No satellite image and air photo are available since 2002 but a series of field observations in 2008 highlight changes happened in the eastern braidplain between which shows that the active braidplain of 1976 (Fig. 5A) is completely abandoned and highly vegetated with trees 4 - GEOMORPHOLOGICAL ANALYSIS

River long profiles of either active or abandoned streams were extracted from the DEM based on stereoscopic $3 \mathrm{~N}$ and $3 \mathrm{~B}$ bands of an ASTER scene and the SRTM DEM.

\section{4.a - River long profiles}

The Rio Pindo Grande that constitutes the northern and eastern boundary of the Puyo fan preserves a low gradient upstream of its confluence with the Rio Puyo. The Rio X shows the steeper and most regular gradient (Fig. 9A), and profile preserves the same regularity until the present Rio Pastaza, with no marked of the upper Rio Puyo remains relatively low in the plateau but increases when approaching the confluence with the Rio X (Fig. 9A). As the gradient of the Rio X remains rather regular in this area, this clearly shows that the greatest part of the over-incision imposed by the backtilt of the plateau was achieved by the 'Pastaza 1906' and predated the avulsions.

The profile of the Rio Pastaza 1906 has been average slope $\left(585 \mathrm{~cm} \cdot \mathrm{km}^{-1}\right.$ for the $16 \mathrm{~km}$ preceding the confluence with the Rio Puyo) steeper than those of the upper Rio Puyo and Rio Pindo Grande (375 and 384 $\mathrm{cm} . \mathrm{km}^{-1}$, respectively) (Fig. 9A). The valley/stream profile of the Pastaza 1906 becomes convex upward in the area where the avulsions occurred (Fig.9B). The profiles of the western and eastern branches of the Pastaza show the steepest slopes (743 and $707 \mathrm{~cm} . \mathrm{km}^{-1}$, respectively) (Fig. 9B). In detail, the profiles of both branches of the present Rio Pastaza downstream of Mera show a marked increase in slope in the area where the main avulsion occurred with an increase, followed by a decrease, in river gradient not related to any bedrock change (Figs. 9B and C).

\section{4.b - River long profile of the 1906 path and plateau profiles}

The reconstructed long profile of the Pastaza 1906, between the avulsion sites and the southward bend, has been compared with two transverse profiles of the plateau in the same area. The first profile is along a straight line at south 
$\sim 1 \mathrm{~km}$ from the 'river' (XX' profile on figure 10). The tectonic backtilting opposing the normal eastward flow second profile is along the northern divide of the former and/or creating more favourable slopes toward the south. drainage basin and projected onto the plane of the first However, even tough the uplift rate generated by profile (yellow dashed line on figure 10A). The two backtilting is relatively high, such a 'mechanical' increase profiles are remarkably similar except the presence along in slope diverting the river course may appear by itself the divide of a local residual relief. The eastern (upper) insufficient for having caused the 1906-to-1976 avulsion if portion of this diagram shows the Pastaza (present eastern we consider that the presently modest Rio Puyo has been branch) incising the upper fan. The convex-upward central able to maintain its eastward course.

portion between the two windgaps (Pastaza - Chigunsimi Figures 6 and 10 show that the area where the avulsions and Chigunsimi - Rio X) corresponds to a low in the occurred is in fact situated in the topographic depression plateau profile with the same slope as the reconstituted between the east-sloping Puyo fan and the west-sloping river. The eastern portion represents the backtilted surface plateau surface, and is marked by a reduction in slope of of the plateau incised by the Pastaza 1906 and presently the 'Pastaza 1906'. The abrupt increase in width and occupied by the lower Rio Puyo (Fig. 10). The incision decrease in river gradient when debouching on to a increases up to $\sim 150 \mathrm{~m}$ near the southward bend at $\sim 4.5$ piedmont (see Fig. 5) reduces bed shear stress, thus $\mathrm{km}$ to the plateau edge (Fig 10). If considering that incision enhancing braiding and aggradation, and promoting commenced at the LGM this yields a minimum average avulsion (Schumm et al., 2000). In another hand, it has incision rate of $7.5 \mathrm{~mm} . \mathrm{yr}^{-1}$. This rate is consistent with the been established that subtle warping is sufficient to induce average uplift rate of the plateau edge (6-8.5 mm/year ${ }^{-1}$, changes in planform geometries (Ouchi, 1985; Holbrook see above).

\section{5 - DISCUSSION} and Schumm, 1999). Again, according to Jones and Schumm (1999): 'gradient reduction in meandering streams may result in bedload deposition where the slope

No other documents than the 1906 map, the 1976 aerial decreases, clogging of the channel, and finally avulsion'. photographs, and the satellite images are presently The 1906-to-1976 avulsion in fact occurred at the braidingavailable on the avulsions and the relations between these meandering transition in an area where the reconstituted avulsions and the volcanic, climatic, and seismic events profile of the 'Pastaza 1906' effectively shows a decrease having occurred in the $20^{\text {th }}$ century cannot be directly in slope (Figs. 9B and 10). An association of gradient observed. However, the eventual role of these events and reduction and abrupt river widening may also be invoked of longer-term events such as aseismic tectonic tilting in for the 1976-to-2008 gradual avulsion which occurs in the the genesis of the avulsions may be discussed in the light same piedmont area where the Pastaza both decreases in of the above data.

\section{5.a - Earthquakes and volcanic eruptions}

slope as a result of tectonic backtilting and enlarges after having been confined in the cordilleran valley. The progressive dominance of the western branch over the

Major earthquakes occurred in 1949, 1987 (Mw 7.1), eastern branch might have been a result of progressive and 1995 (Mw 7.0) (Yepes et al., 1996; Legrand et al., starving of the eastern branch by tectonically-enhanced 2005, Fig. 1A), that is, between the making up of the 1906 aggradation upstream of the initial avulsion site. map and 1976, just before or after the 1987 photographs, Aggradation enhanced by tectonic tilting seems, therefore, and between the 1992 and 2000 images. Relatively high to have played a major role in the genesis of the avulsions magnitudes earthquakes are frequent (Fig. 1A). However, by leading the system close to the avulsion threshold as the stepped terraces that bound both branches of the stated by Jones and Schumm (1999). Previous steepening Pastaza (Bès de Berc et al., 2005; Fig. 6), show that and narrowing of the valley downstream of the avulsion aggradation has proceeded there without constructing site might explain why a former left-bank tributary of the levees to be breached by earthquakes as, for example, in Pastaza - the Rio Puyo - could have continued to flow in the Rhine-Meuse delta (Stouthamer and Berendsen, 2000; this valley after the Pastaza was beheaded.

Cohen et al., 2002). There are no more evidences of transverse faults having diverted the Pastaza.

Major eruptions of Tungurahua volcano producing pyroclastic flows and ash falls occurred in 1916-18 and 2006-08 (Le Pennec et al., 2008; IGEPN, 2009). However, the amount of material delivered to the the Pastaza was relatively limited and none of these major eruptions was capable of transporting ash surges or lahars necessary for triggering avulsions down to the study area (Le Pennec et al., 2008; IGEPN, 2009).

\section{5.b - Tectonic tilting}

The westward migration of the Pastaza and the development of the western branch at the expense of the eastern branch apparently agree with the interpretation that the Pastaza simply migrated westward as a result of

\section{5.c - Capture/annexation of a pre-existing river}

The longitudinal depression in which flow the present western and eastern branches of the Pastaza was created by tectonic backtilting tilting and arching (Fig. 3). This depression has had a slope steeper than the original slope of the river, which may have provided a more favourable way to the Pastaza (Jones and Schumm, 1999; Slingerland and Smith, 2004; Humphrey and Konrad, 2000). This depression was occupied by a former tributary to the Rio Llushin potentially able to capture the Pastaza by headward erosion (e.g. Summerfield, 1991). Another possibility should be that the Pastaza, made unstable because of increasing aggradation and decreasing slope, annexed this tributary (avulsion by annexation according to Slingerland and Smith, 2004; 'capture par déversement' (= 
capture by overflow) as opposed to capture by headward 1976 the vegetation in the abandoned meander belt was too erosion in the French literature, see e.g. Tricart, 1952 or high for the abandon to have occurred recently. These Coque, 2002 p. 120-121). This latter interpretation will be avulsions may have been triggered by ENSO events older preferred as it accounts for both the shape of the long than those recorded in the hydrograms of the Baños profile of both branches of the Pastaza and the wind gaps station, probably the 1942 or 1916 La Niña events as being constituted by an accumulation of sediment at the suggested by the height of the trees greater than 20-30 m braiding/meandering transition. and the state of evolution of the forest.

\section{5.d - ENSO events}

Severe ENSO events occurred in 1916, 1942, 1949 ,

\section{6 - CONCLUSIONS} 1955, 1969-1970, 1971-1972, 1974-1975, 1975-1976, eastern Subandean Zone of Ecuador (Puyo plateau) over 1982-1983 and 1997-1998 (Aalto et al., 2003). The major the last century reveals 3 westward avulsions. The main avulsions observed in our study area occurred between avulsion was achieved in the period 1906-to-1976 by the 1906 and 1976, between 1987 and 1992, and between 1992 annexation of a smaller river flowing in a south-sloping and 2000. The hydrograms available for our study area wide tectonic depression formed along the front of the (Baños hydro-meteorological station, Fig. 2) only cover the cordillera. A second, smaller-sized, avulsion affecting the period 1963 - 2006. Figure 4 shows that the peaks in beheaded portion of the river occurred in the same period. annual discharge associated with La Niña events occurred The third avulsion occurring in the period 1976-to-2008 is in periods preceding the avulsions. The partial avulsion characterized by a gradual shift of flow from the previous having formed the western branch may have been triggered avulsive channel to a newly formed westward channel. by the 1975-1976 and 1974-1975 La Niña events (highest This partial avulsion involves two branches which have codischarges yet measured) and/or the preceding 1971-1972 existed for more than 30 years. The eastern branch formed and 1969-1970 events. The 1988-1989 La Niña events first with its channel pattern evolving from highly braided occurred in the period 1987-1992. The 1998-1999 and to single channel. All these three avulsions have been 1999-2000 La Niña events immediately preceded the controlled by the interplay of the progradation of a braided changes observed in 2000. The peaks in annual discharge alluvial fan formed by the Rio Pastaza and tectonic tilting during La Niña events are not much higher than the continuously increasing the hinterland-dipping topographic average: $\sim 185 \mathrm{~m}^{3} \mathrm{~s}^{-1}$ for the 1975-1976 and 1974-1975 slope. Tectonic backtilting may have acted by enhancing events, $\sim 165-170 \mathrm{~m}^{3} \mathrm{~s}^{-1}$ for the 1971-1972 and 1969-1970 aggradation upstream of the initial site to generate a second events, and $\sim 150 \mathrm{~m}^{3} \mathrm{~s}^{-1}$ for the the1998-1999 and 1999- avulsion site, in the same time as it offered the avulsed 2000 events vs. $121 \mathrm{~m}^{3} \mathrm{~s}^{-1}$ for the average annual discharge channel a more favourable longitudinal way along the but significantly higher than the 'normal' variations (see cordillera.

Fig. 4B). As observed by Wells and Dorr (1987) in the Kosi megafan and discussed by Jones and Schumm (1999), exceptional floods are not necessary for triggering avulsions if other conditions make the river close to the sed avulsion threshold. However, the Kosi fan is 'very flat' and aggradation rapid (Wells and Dorr, 1987) and 'normal' flood are important because of this flat attitude of the fan stur and of the monsoonal regime of the region. In the Puyo area and the Amazonian domain in general, floods were not registered in the hazard records, except during La Niña events (Demoraes and D'Ercole, 2001). In fact, the flat shape of the average monthly discharge curve (Fig. 4A), due to different precipitation regimes in various parts of the upper catchment, does not allow large 'normal' floods and leaves them no great chance of triggering avulsions. As actual floods only occur during La Niña events, the correlation between stronger ENSO events and the avulsions cannot be a simple coincidence. According to Aalto et al. (2003) not only water but also sediment discharge considerably and rapidly increased during La Niña events (Aalto et al., 2003) and most of the aggradation in the Andean floodplains has occurred during La Nina events. Therefore, La Niña events should have enhanced aggradation in the same time as they caused flooding.

The main avulsion from the Pastaza 1906 to the eastern branch and the avulsion of the Rio X into the Rio Putuimi are obviously much older than 1976 as it is clear that in

In this framework, the cause and trigger of avulsions could be (1) tectonic backtilting ontop of the propagating Subandean Front creating a favourable topographic and sedimentary setup for avulsions, and (2) ENSO (La Niña) events which are responsible for much higher water and sediment discharges and in the climatic context of the study area are the only events able to cause floods and enhance aggradation.

\section{ACKNOWLEDGEMENTS}

This study benefited of the logistic and financial support of the IRD (French Institute for Research in Development). This investigation was supported by a doctoral Alßan fellowship (no E05D057404EC). The

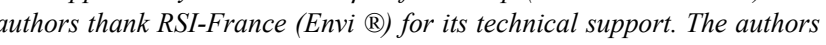
thank J.M. Holbrook, J-D. Champagnac and a third anonymous reviewer for their help in improving this article.

\section{REFERENCES}

Aalto R, Maurice-Bourgoin L, Dunne T, Montgomery DR, Nittrouer C, Guyot J-L (2003) Episodic sediment accumulation on Amazonian floodplains influenced by El Niño/Southern Oscillation. Nature, 425:493-497.

Baby P, Rivadeneira M, Christophoul F, Barragán R (1999) Style and timing of deformation in the Oriente of Ecuador, in Orstom, ed., 4th International Symposium of Andean Geodynamics, Volume 1: Göttingen, ORSTOM, 68-72.

Baldock JW (1982) Boletín de Explicación del Mapa Geológico del Ecuador: Quito, Ecuador, DGGM, 80 pp. 
Barragán R, Baudino R, Marocco R (1996) Geodynamic evolution of the Laraque A, Bernal C, Bourrel L, Darrozes J, Christophoul F, Fraizy P, Neogene intermontane Chota basin, northern Andes of Ecuador. Journal of South American Earth Sciences. 9:309-319.

Barberi F, Coltelli M, Ferrara G, Innocenti F, Navarro JM, Santacroce R (1988) Plio-Quaternary volcanism in Ecuador. Geological Magazine, 125:1-14.

Bernal C, Christophoul F, Darrozes J, Soula J-C, Baby P, Burgos JB (2011) Late Glacial and Holocene avulsions of the Rio Pastaza Megafan (Ecuador-Peru ): frequency and controlling factors, International Journal of Earth Sciences (Geologische Rundschau), 100:1759-1782, doi 10.1007/s00531-010-0555-9.

Bès de Berc S, Soula J-C, Baby P, Souris M, Christophoul F, Rosero J (2005) Geomorphic evidence of active deformation and uplift in a modern continental wedge-top - foredeep transition: example of the eastern Ecuadorian Andes: Tectonophysics, 399:351-380.

Brierley GJ (1989) River planform facies models: the sedimentology of braided, wandering and meandering reaches of the Squamish River, British Columbia. Sedimentary Geology, 61:17-35, doi 10.1016/0037-0738(89)90039-0.

Cohen KM, Stouthamer E, Berendsen HJA (2002) Fluvial deposits as a record for Late Quaternary neotectonic activity of the Rhine-Meuse delta, the Netherlands. Netherlands Journal of Geosciences / Geologie en Mijnbouw, 81:389-405.

Coque R (2002) Géomorphologie, $6^{\text {th }}$ edition, Armand colin, Paris, 503 pp.

Demoraes F, D'Ercole, R., 2001. Cartografía de riesgos y capacidades en el Ecuador. Diagnóstico previo a planes de intervenciones de las ONG's. Internal report. COOPI-IRD-OXFAM, Quito (Ecuador)Université de Savoie (France) Internet site. 65.

Gomez N (1994) Atlas del Ecuador, Geografia y Economia. Imagenes de la Tierra, 3, Editoria Ediguias C. 1tda, Quito, 114pp.

Harvard Catalog, 1999. Hervard Seismology, CMT Catalog Search (updated

http://www.seismology.harvard.edu/CMTsearch.html.

1999).

Hastenrath S (1981) The glaciation of the Ecuadorian Andes, Balkemma, Rotterdam, The Netherlands, $159 \mathrm{pp}$.

Heine K (1994) The Mera site revisited: Ice-age Amazon in the light of new evidence. Quaternary International, 21:113- 119.

Heine K (2000) Tropical South America during the Last Glacial Maximum: evidence from glacial, peri-glacial and fluvial records. Quaternary International, 72:7-21.

Hoffer G, Eissen J-P, Beate B, Bourdon E, Fornari M Cotten J (2008) Geochemical and petrological constraints on rear-arc magma genesis processes in Ecuador: The Puyo cones and Mera lavas volcanic formations. Journal of Volcanology and Geothermal Research, $176: 107-118$

Holbrook J, Schumm SA (1999) Geomorphic and sedimentary response of rivers to active deformation: a brief review and critique of a tool for recognizing subtle epiorogenic deformation in modern and ancient settings. Tectonophysics, 305:287-306.

Hungerbühler D, Steinmann M, Winkler W, Seward D, Egüez A, Person DE, Helg U, Hammer C, 2002, Neogene stratigraphy and Andean geodynamics of southern Ecuador. Earth Science Review, 57:75-124.

Humphrey NF, Konrad SK (2000) River incision or diversion in response to bedrock uplift. Geology, 28:43-46.

IGEPN, 2009, http://www.igepn.edu.ec, Instituto Geofisico de la Escuela Politecnica Nacional, Quito, ecuador.

Jones LS, Schumm S.A. (1999) Causes of avulsion: an overview, in Smith, N.D., and Rogers, J., eds., Fluvial Sedimentology VI, Special Publication of the International Association of Sedimentologists, Blackwell Science, 28:171-178.

Kennerley JB (1980) Outline of the Geology of Ecuador. Overseas Geological and Mineral Resources, 55:1-16. Pombosa R, Guyot J-L (2009) Sediment budget of the Napo River, Amazon Basin, Ecuador and Peru. Hydrological Processes, 23:35093524, doi: 10,1002/hyp,7463.

Lavenu A, Noblet C, Bonhomme MG, Egüez A, Dugas F, Vivier G, (1992) New K-Ar age dates of Neogene and Quaternary volcanic rocks from the Ecuadorian Andes: Implications for the relationship between sedimentation, volcanism, and tectonics. Journal of South American Earth Sciences, 5:309-320.

Legrand D, Baby P, Dorbath C, Bès de Berc S, Rivadeneira M (2005) The 1999-2000 seismic experiment of Macas swarm (Ecuador) in relation with rift inversion in Subandean foothills. Tectonophysics, 395:6780 .

Le Pennec JL, Jaya D, Samaniego P, Ramon P, Moreno Yanez S, Egred J, van der Plicht J (2008) The AD 1300-1700 eruptive periods at Tungurahua volcano, Ecuador, revealed by historical narratives, stratigraphy and radiocarbon dating. Journal of Volcanology and Geothermal Research, 176:70-81.

Ouchi S (1985) Response of alluvial rivers to slow active movement. Geological Socitey of America Bulletin, 96:504-515.

Reynaud C, Jaillard E, Lapierre H, Mamberti M, Mascle G (1999) Oceanic plateau and island arcs of south-western Ecuador: their place in the geodynamic evolution of north-western South America. Tectonophysics, 307:235-254.

Schumm SA (1977) The Fluvial System, The Blackburn Press, 358 pp.

Schumm SA, Dumont J-F, Holbrook JM (2000) Active tectonics and alluvial Rivers: Cambridge, Cambridge University Press, $401 \mathrm{pp}$.

Slingerland R, Smith ND (2004) River avulsion and their deposits. Annual Reviews of Earth and Planetary Science, 32:257-285.

Stouthamer E, Berendsen HJA (2000) Factors Controlling the Holocene Avulsion History of the Rhine-Meuse Delta (The Netherlands). Journal of Sedimentary Research, 70:1051-1064.

Summerfield MA (1991) Global Geomorphology. An Introduction to the Study of Landforms. Harlow, Longman, 537pp.

Tricart J (1952) La partie orientale du bassin de Paris, étude morphologique, Sédes, Paris, 467pp.

Tschopp HJ (1953) Oil explorations in the Oriente of Ecuador. American Association of Petroleum Geologists Bulletin, 37:2303-2347.

Wells NA, Dorr JA (1987) Shifting of the Kosi River, Northern India. Geology, 15: 204-207.

Winkler W, Villagomez D, Spikings R, Abegglen P, Tobler S, Egüez A (2005) The Chota basin and its significance for the inception and tectonic setting of the inter-Andean depression in Ecuador. Journal of South American Earth Sciences. 19:5-19

Yepes H, Chatelain J-L, Guillier B, Alvarado A, Egred J, Ruiz M, Segovia M (1996) The Mw 6.8 Macas Earthquake in the Subandean Zone of Ecuador, October 3, 1995. Seismological Research Letter 67:27-32. 


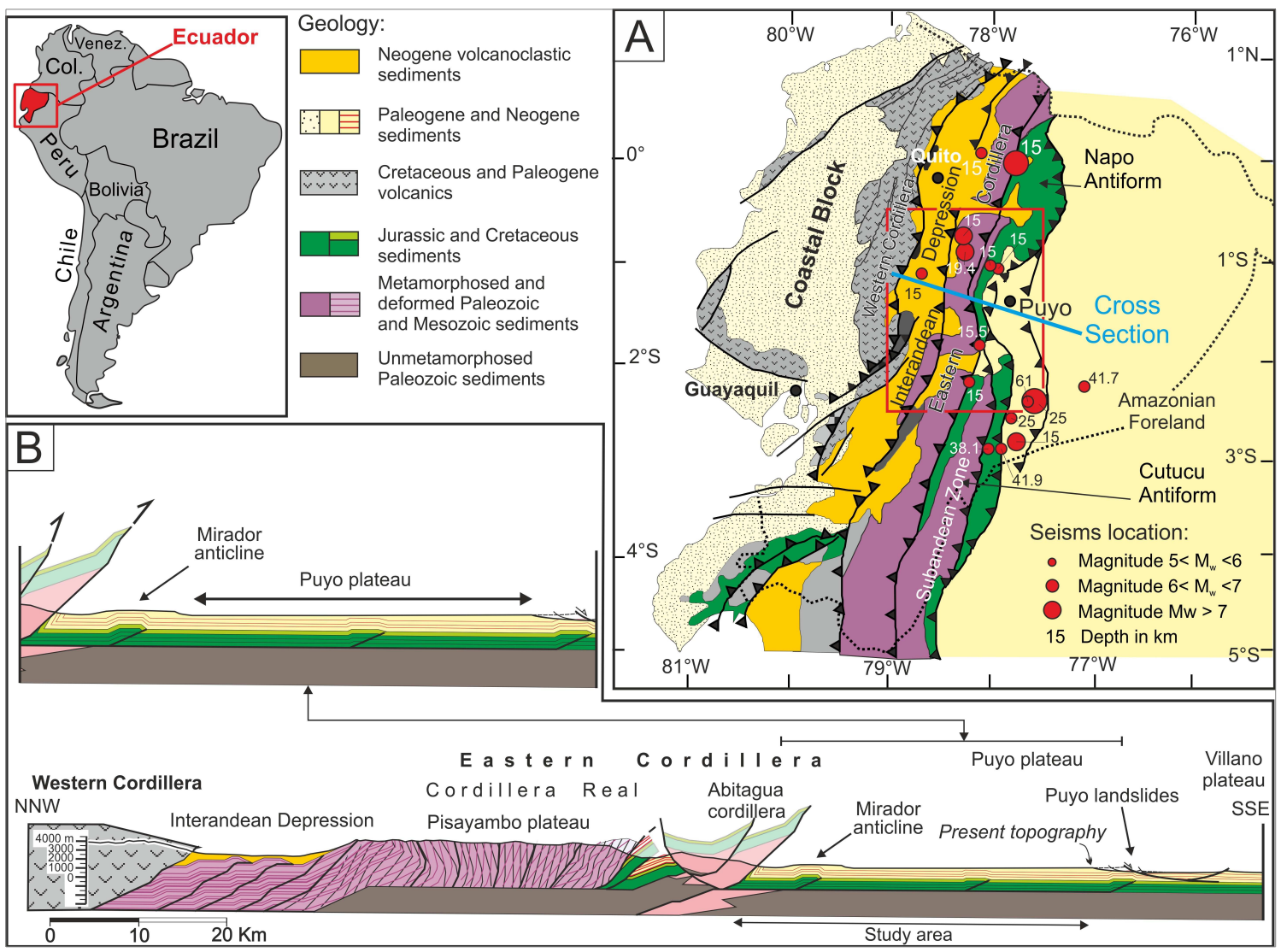

Figure 1: Simplified geological map of Ecuador, structural cross section, location of the seismic A: simplified geological map of the Ecuadorian Andes and location of the seismic activity. Solid black lines: mains thrusts faults of Ecuadorian Andes. Solid red line: location of fig. $1 B$ Location and depth of earthquakes with magnitude greater than $M_{w} 5$ in the study area, between $77^{\circ} \mathrm{W}$ and $79^{\circ} \mathrm{W}$ and between $1^{\circ} \mathrm{N}$ and $3^{\circ} \mathrm{S}$ between 1976 and 1999 (Harvard Catalog ,1999). B: Depth of earthquakes with magnitude greater than $M_{w} 5$ in the study area, between $77^{\circ} \mathrm{W}$ and $79^{\circ} \mathrm{W}$ and between $1^{\circ} \mathrm{N}$ and $3^{\circ} \mathrm{S}$, between $\mathrm{AD} 1976$ and 1999 (Harvard Catalog ,1999). B: Structural cross section across the western cordillera, the interandean depression, the eastern cordillera, the subandean zone and the amazonian foreland. Cross section is striking $N W$-SE, location on the geological map exhibited in A. 


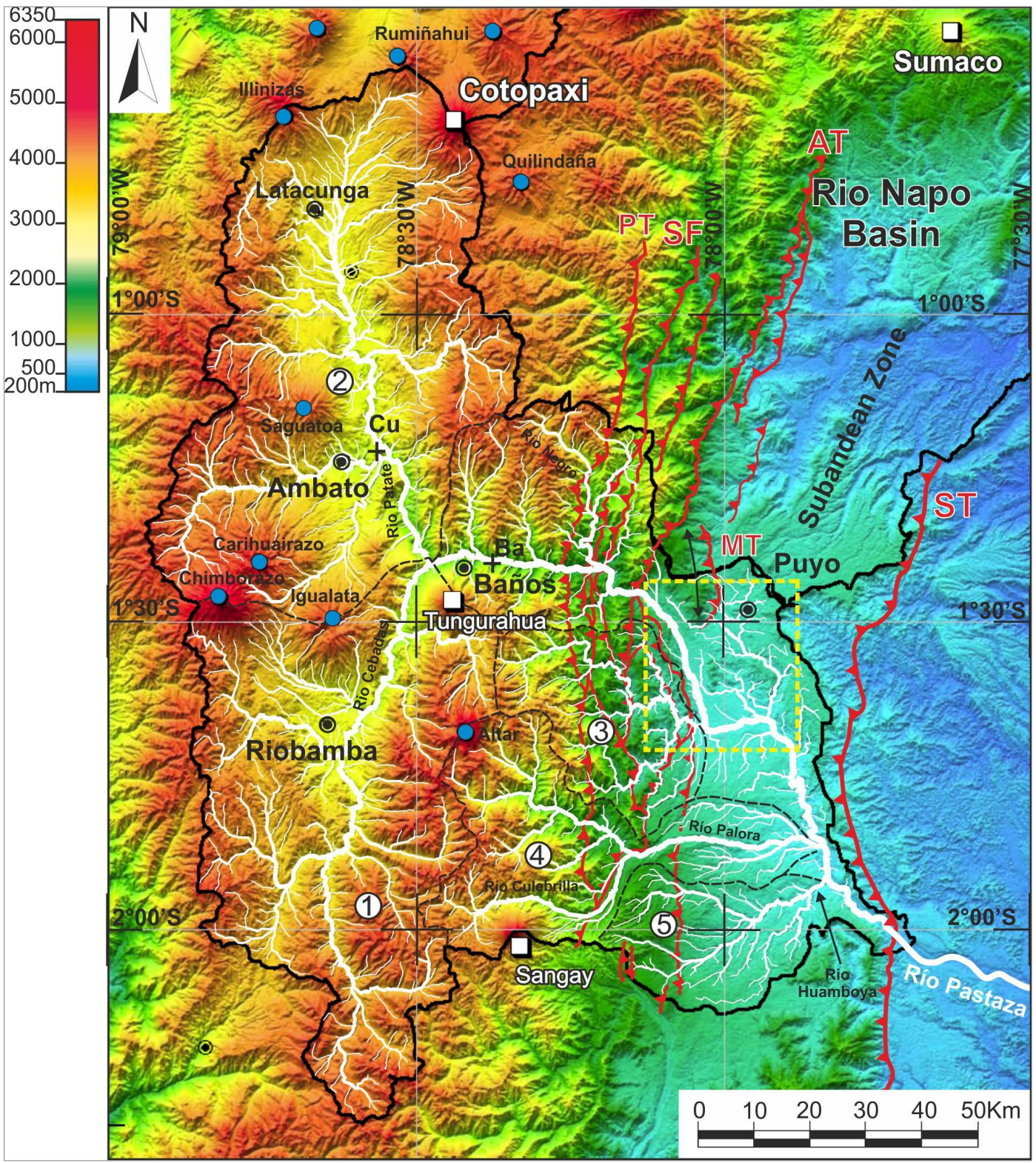

Figure 2: SRTMV3 DEM (90m accuracy) of the Ecuadorian Andes. White squares: actives volcanoes. Blue spots: inactive volcanoes. Solid black line: watershed divide of the Rio Pastaza and Napo basins. Dashed black lines: sub-basins divide, 1: Rio Cebadas, 2: Rio Patate, 3: Rio Llushin, 4: Rio Culebrilla, 5: Rio Huamboya. Solid white lines: hydrographic network, thickness of lines grows with Stralher order (tributaries represented have order $>3$ ). Solid red lines: main thrusts faults of the eastern cordillera and subandean zone. PT: Pallatanga Thrust, SF: Subandean Fault, AT: Abitagua Fault, MT, Mirador Thrust, ST: Subandean Thrust. Yellow dashed lines: area of avulsions of the Rio Pastaza. The Puyo Plateau is the light blue to light green (750-1,100m asl) area comprised between the ST to the east and the thrust-faults at the front of the Eastern Cordillera (involving the MT) to the west. Black crosses: location of hydrometeorological stations which provided data exposed on Fig.4. Cu: Cusubamba Station, Ba: Baños Station. 


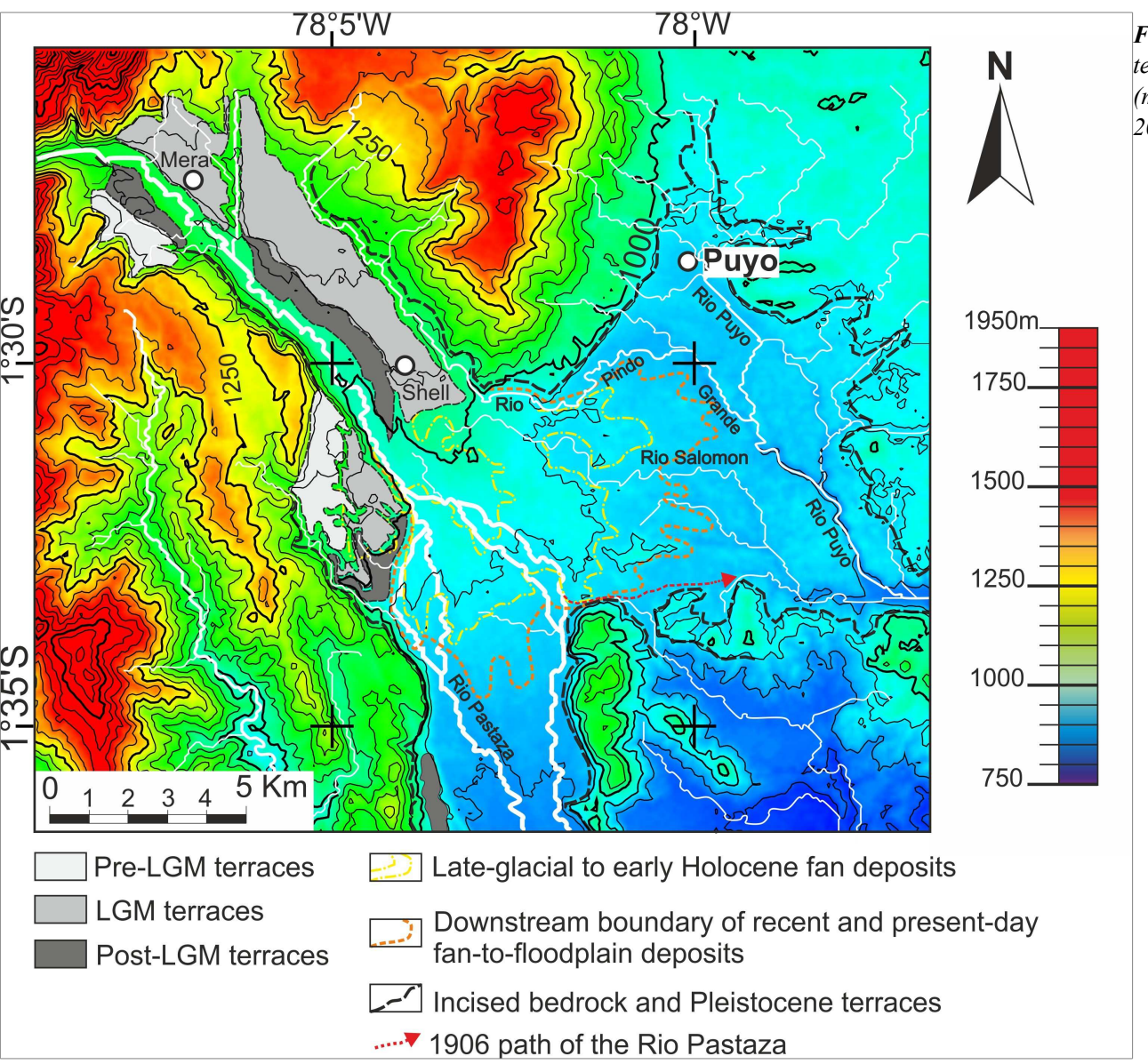

Figure 6: Map of Pleistocene and Holocene alluvial terraces and alluvial fan deposits of the Puyo area (modified from Bes de berc et al, 2005 and Burgos, 2006).

..... 1906 path of the Rio Pastaza 


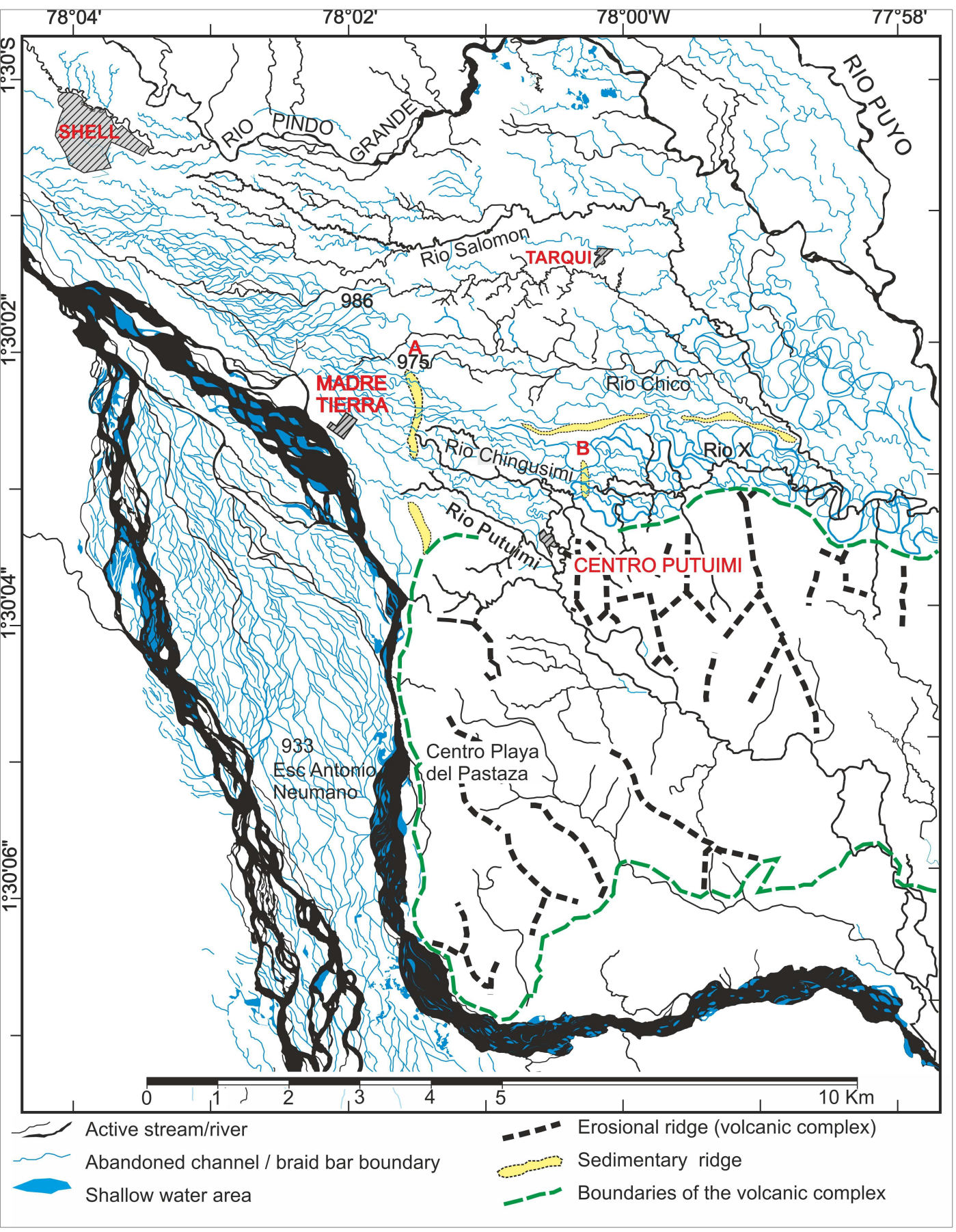

Figure 7: Photo-interpretated map of the fluvial features of the Puyo area. Map based on aerial photographs exhibited on Fig. 5A. Active channels in 1976 are represented in black, braid bars in blue. Yellow areas corresponds to topographic highs interpreted as sedimentary ridges deposited on the former banks of the channels. Inactive and abandoned channels are represented with blue lines. To the west, in the north-south reach of the Rio Pastaza, the pattern of inactive and abandoned channels is typical of a braided river. In the north (east of Madre Tierra and Tarqui), the abandoned channel patterns evolves from west to east from a braided to meandering channel pattern. The active reach (north-south) and the abadoned one (west-east) are separated by the volcanic complex (bounded by a dashed green line). 

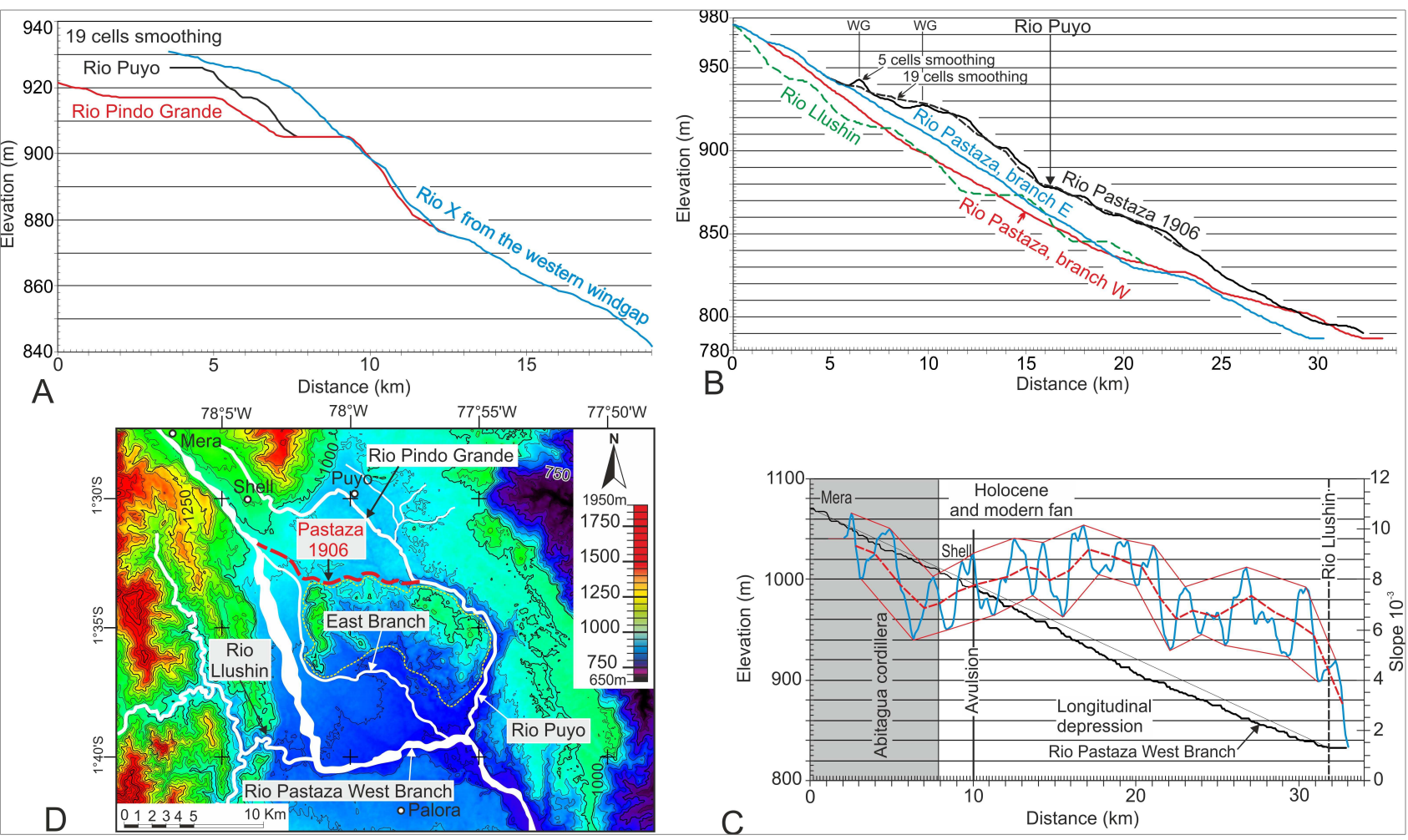

Figure 9: Long profiles of the main rivers flowing in the central Puyo plateau. Elevations in $\mathrm{m}$; distances in $\mathrm{km}$. A: Profiles of the Rio X, Rio Puyo and Rio Pindo Grande down to the $90^{\circ}$ bend of the Rio Puyo from the SRTM DEM. The profiles have been smoothed using average value in a 19 cells $(\sim 1,700 \mathrm{~m})$ moving windows filter. The Rio X continued by the lower Rio Puyo downstream of the confluence of these rivers shows the most regular profile. No change in the profile of the Rio $X$ is observed at the confluence whereas the gradient of the Rio Puyo abruptly deceases $\sim 3 \mathrm{~km}$ upstream of this confluence. B: Profiles of the eastern and western branches of the Pastaza starting from the divergence area compared with the reconstituted profile of the 'Rio Pastaza 1906). The present day wind gaps well appear using a 5 cells moving window filter and are smoothed by using a 19 cells moving window filter. In any case, the profile takes a convex-upward shape in the area where the avulsions occurred. Note that both branches of the Pastaza have a steeper gradient than the original course. The profile of the transverse Rio Llushin in the front of the cordillera has been added. Although being more irregular because of alternating longitudinal and transverse reaches, this profile shows an average gradient similar to those of both branches of the Pastaza. C: Long profile and slope of the Pastaza (eastern branch) from Mera to the confluence with the Rio Llushin. The gradient appears to be steeper in the longitudinal depression immediately downstream of the avulsion site than between Mera and Shell where the river traverses the Abitagua cordillera. The slope (blue line) decreases between Mera and Shell, then increases in the upper part of the longitudinal depression, and finally, decreases toward the confluence with the Rio Llushin. Slopes values are computed with 5 pixels segments (blue line). The red lines above and below the blue curve corresponds to the minimum and maximum enveloppe curves of slope values. D: Location map of the profiles presented in $A, B$ and $C$. The topographic map is based on the DEM used for profiles extraction. 
